\title{
FIRST RECORDED OCCURRENCE OF CREEPING MAHONIA (BERBERIS REPENS Lindley) IN SASKATCHEWAN
}

ALAN DODD, Rangeland Conservation Service Ltd \#502, 2903 Kingsview Boulevard SE Airdrie, Alberta T4A 0C4

\section{Introduction}

The first recorded population of creeping mahonia (Berberis repens Lindley) was observed in Saskatchewan. A single population was observed in Cypress Hills Inter-provincial Park (CHIP) - West Block in August 2011. The species was originally observed in 2002 at the same location but the discovery went unrecognized. This new population represents a significant extension of the known range of the species, as the closest known populations are in southwestern Alberta and central Montana. The discovery of creeping mahonia is a significant addition to the unique flora of the Cypress Hills.

\section{Background}

\section{Cypress Hills}

The Cypress Hills are centred on lat. 49 30' N, long. 110 W on the Canadian Great Plains, approximately $70 \mathrm{~km}$ north of the United States border. They extend for approximately $130 \mathrm{~km}$ along an east-west axis through southwestern Saskatchewan and southeastern Alberta. North-south, the Hills are typically only about $15 \mathrm{~km}$ wide, although they do reach a width of $25 \mathrm{~km}$ in places. In total, the Cypress Hills cover nearly $2600 \mathrm{~km}^{2}$ of land.

CHIP is divided into three blocks: Elkwater in Alberta and the West and Centre blocks in Saskatchewan. The West Block is located adjacent to the Elkwater Block on the opposite side of the provincial boundary and approximately
$16 \mathrm{~km}$ west of the Centre Block. The West Block covers approximately 13,880 hectares $(34,300$ acres) of land, and is located approximately $40 \mathrm{~km}$ southwest of the town of Maple Creek in Townships 7 and 8, Ranges 28 and 29 W3M.

The primary ecological factor differentiating the Cypress Upland from other ecoregions is elevation. ${ }^{1}$ Highest elevations in the Hills are near Elkwater, Alberta and lowest near Eastend, Saskatchewan. Elevation ranges from approximately $1,463 \mathrm{~m}(4,810 \mathrm{feet})$ to $1,000 \mathrm{~m}(3,300$ feet $)$ between these two locations.

Elevation has dramatic effects on vegetation in the Cypress Upland. There are two main habitat types in the ecoregion: grassland and forest. Mixed grassland occurs at elevations between $775 \mathrm{~m}$ (2,550 feet) and 1,000 $\mathrm{m}(3,300$ feet) on the north slope and between $850 \mathrm{~m}(2,800$ feet) or $950 \mathrm{~m}$ $(3,100$ feet) (depending on location) and $1,050 \mathrm{~m}(3,450$ feet) on the south slope. ${ }^{1}$ Grassland at higher elevations is dominated by rough fescue (Festuca campestris and $F$. hallii). The reference community on the Loam ecosite (Dark Brown and Black Chernozemic soils) in the Cypress Upland is described as rough fescue (average cover $=30 \%)^{2}$

Forests are more prevalent in the west part of the Cypress Hills. Forest in the Cypress Hills occurs primarily on 
north aspects as well as in some of the valleys on the plateau. In the West Block, lodgepole pine (Pinus contorta) and aspen (Populus tremuloides) are the dominant tree species, with lesser amounts of white spruce (Picea glauca) and balsam poplar (Populus balsamifera). Lodgepole pine reaches its greatest extent in the West Block, and occurs at elevations between $1,280 \mathrm{~m}(4,200 \mathrm{ft})$ to $1,465 \mathrm{~m}(4,800 \mathrm{ft}){ }^{3}$ Aspen forest is typically found at lower elevations immediately below lodgepole pine forests in the West Block, as well as in mixed stands with white spruce. White spruce is generally found in cool, moist habitats associated with springs as well as along Battle Creek. ${ }^{3}$

The forests of the Cypress Hills were originally described as boreal forest outliers ${ }^{4}$ and boreal-cordilleran transition forests. ${ }^{5}$ Other authors emphasized the Cordilleran influence. ${ }^{3,6}$ The Cypress Hills are included in the Rocky Mountain Natural Region in Alberta ${ }^{7,8,9,10}$ and the Cypress Upland Ecoregion in Saskatchewan, which is described as an outlier of the montane vegetation zone. ${ }^{11}$

\section{Creeping Mahonia}

Creeping mahonia is a member of the Berberidaceae family. It is an evergreen shrub $2 \mathrm{~cm}$ to $20 \mathrm{~cm}(60 \mathrm{~cm})$ tall. $^{12}$ Its leaves are (3-) 5 to 7 foliolate with thin, flexible, usually dull and somewhat glaucous leaflets which have numerous spine-tipped teeth. The inflorescence is densely racemose with 25 to 50 flowers that produce blue berries. The species flowers from April to June.

The habitat of creeping mahonia is described as mountain woods, ${ }^{13}$ forests from foothills to lower montane elevations, ${ }^{14}$ open forest, shrub, and grassland, ${ }^{12}$ and dry rocky slopes and open forests in the steppe and montane zones. ${ }^{15}$

Creeping mahonia has not been previously recorded in Saskatchewan (Enns pers. comm.). ${ }^{16}$ Nature Serve lists creeping mahonia as growing in British Columbia, Alberta, and Ontario in Canada. ${ }^{17}$ In Alberta, it occurs in the southwest part of the province from Waterton Lakes National Park in the south

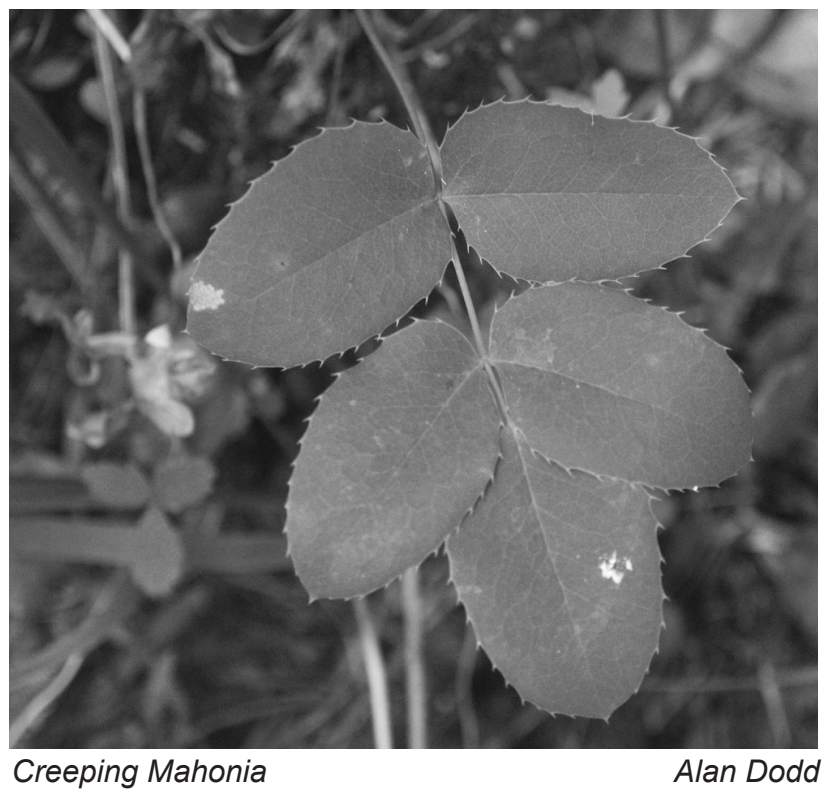


to the Crowsnest Pass in the north. ${ }^{13}$ In British Columbia, it is described as common in the southeast and rare in the central and south-central parts of the province. ${ }^{15}$ In the United States, creeping mahonia is found in 19 states, including the bordering states of Washington, Idaho, Montana, and North Dakota. ${ }^{17}$ The closest known populations to the Cypress Hills are in the foothills of southwestern Alberta and in central Montana, ${ }^{13,18}$ both of which are approximately $300 \mathrm{~km}$ from the observed Saskatchewan population.

Creeping mahonia is considered Secure (S5), Vulnerable (S3), and Exotic in British Columbia, Alberta, and Ontario, respectively. ${ }^{17}$ Creeping mahonia is not ranked or under review (SNR/SU) in Washington and Idaho. It is listed as Secure in Montana and Imperiled (S2) in North Dakota.

\section{Findings}

Creeping mahonia was first discovered in CHIP - West Block in 2002 by RCS staff during a range inventory of the park, in which a number of transects were established in forest and grassland communities throughout the block. However, the significance of the discovery was not realized at the time. The species was observed along only one of fourteen forest transects established in 2002. The transect was located in a white spruce aspen mixedwood forest community in the southeast part of the West Block.

During a range re-assessment of the West Block in 2011, creeping mahonia was observed along the same transect, but as in 2002, at none of the others. Approximately 30 plants were observed along the transect in 2011, although a detailed, systematic count was not conducted due to time constraints. A park closure due to fire hazard prevented a second visit to the park later in the season to conduct a detailed population count. Creeping mahonia occurred in two of the ten quadrats along the transect. The forest community was described as Healthy according to the Saskatchewan Range Health protocol. ${ }^{19}$

Plant species occurring in the same quadrat as creeping mahonia included smooth wild rye (Elymus glaucus), whitegrained mountain rice grass (Oryzopsis asperifolia), wild white geranium (Geranium richardsonii), snakeroot (Sanicula marilandica), buckbrush (Symphoricarpos occidentalis), wild strawberry (Fragaria virginiana), veiny meadow rue (Thalictrum venulosum), western Canada violet (Viola canadensis), Lindley's aster (Aster ciliolatus), common pink wintergreen (Pyrola asparifolia), cream-colored vetchling (Lathyrus ochroleucus), and spreading sweet cicely (Osmorhiza depauperata). Smooth wild rye and wild white geranium are also considered rare in Saskatchewan. ${ }^{20}$

No flowers or berries were present on the creeping mahonia plants observed. However, the characteristic leaves make this species readily identifiable. Nevertheless, a specimen was collected and taken to the University of Calgary herbarium where its identification was confirmed by the assistant curator (Smith pers. comm.).

Interestingly, a leaf specimen collected of creeping mahonia by the author seemed to have more teeth than mentioned in the literature. The Flora of North America describes creeping mahonia leaflets as having 15 to 24 teeth. ${ }^{12}$ However, The Flora of the Pacific Northwest describes creeping mahonia as having 15 to 43 teeth. ${ }^{14}$ Teeth number is not mentioned in the Flora of Alberta. ${ }^{13}$ The specimen collected in CHIP had between 38 and 48 teeth. 


\section{Discission}

A number of botanical studies and inventories have been conducted in the Cypress Hills. ${ }^{3,6,21}$ A number of range inventories and assessments that included a vegetation inventory component have also been completed in the Centre, West, and Elkwater blocks of CHIP. ${ }^{22,23,24,25}$ The fact that creeping mahonia had not been observed prior to 2002 suggests that the species may be quite rare in the Cypress Hills. White spruce - aspen mixedwood forest is also limited in extent in the West Block. Assuming creeping mahonia favours this plant community type in the Cypress Hills, then this adds to the potential rarity of the species at this location. Moreover, the size of the creeping mahonia population observed was apparently quite small. All these factors suggest that future management planning in the park take into consideration any activity that could potentially impact the creeping mahonia population, including forestry, recreational, and livestock grazing activities.

Further surveys are necessary to determine the entire extent of creeping mahonia in the Cypress Hills. Because creeping mahonia was found in white spruce - aspen mixedwood forest, future surveys should be directed to these plant community types. A number of the fourteen transects surveyed by RCS were located in white spruce - aspen mixedwood forest. These stands were found in various locations throughout the south and west parts of the West Block.

As previously discussed, the closest known populations of creeping mahonia to the Cypress Hills population are in montane habitat in southwestern Alberta and central Montana. The Cypress Hills population thus represents a range extension of approximately $300 \mathrm{~km}$. However, the Cypress Hills population is isolated from these other two populations due to the long distance and lack of montane habitat, and is thus an outlier. The occurrence of creeping mahonia in the Cypress Hills further supports the description of the flora as having a distinct Cordilleran influence. Genetic work is needed to determine if there are any differences to other populations.

Creeping mahonia is sometimes planted as an ornamental in xeriscape gardens. And, as previously discussed, it is found in Ontario as an exotic species. Thus, there exists the possibility that creeping mahonia was introduced into CHIP in recent years. However, this event seems unlikely as the creeping mahonia population observed in the park was located in a fairly remote area, away from any known trails. Most visitors to the park follow existing roads and trails, none of which passed through the community creeping mahonia was observed within.

Recent dispersal into the park by other means seems unlikely for several other reasons as well. As previously discussed, creeping mahonia produces blue berries, each of which contains several large seeds. The species is thus not adapted to long distance wind dispersal. Moreover, although the plant is sometimes consumed by wild ungulates, it is not a preferred food source.$^{26}$ Even if berries were consumed by an ungulate, the long distance from other known creeping mahonia populations argues against this type of dispersal. Dispersal by birds also seems unlikely, although not impossible, given when the berries develop (i.e., mid-summer) and when the majority of birds migrate north (i.e., April to May).

A far more likely explanation for the presence of creeping mahonia in the Cypress Hills is that it has been there for quite some time. The association of 
creeping mahonia to other Cordilleran species is likely the key to the explanation of the species' presence in the Cypress Hills. But is its presence in the Cypress Hills an indication that the area was a refugium, or did the species arrive after the melting of the last continental ice sheet?

In a study of land snails in the Cypress Hills, it was argued that the lack of endemic species and proximity of the surrounding ice sheet during continental glaciation supported the conclusion that the Cypress Hills were not a refugium for pre-glacial biota. ${ }^{27}$ Instead, the author concluded that the flora and fauna of the hills must have colonized from the southwest in the early post-glacial period. Other authors have pointed to the presence of rare alleles and distinctive cone and seed traits in lodgepole pine as possible evidence the Cypress Hills acted as a refugium. ${ }^{28,29}$ However, recent research supports the conclusion that creeping mahonia and other Cordilleran species likely colonized the Cypress Hills during de-glaciation.

Recently developed paleovegetation zonal models suggest that Cordilleran forest expanded northward from the western United States during de-glaciation and was present in the Cypress Hills area approximately 14,000 years BP. ${ }^{30}$ As the ice sheet moved north of the Cypress Hills, conditions in the area surrounding the hills became favourable for the development of a grassland ecosystem, which has remained the case ever since. Thus, colonization of Cordilleran vegetation after 14,000 years BP became increasingly unlikely. The aforementioned high elevation of the hills prevented them from becoming dominated by grassland, and could have allowed creeping mahonia and other Cordilleran species to persist to the present day.
A possible northward shift of creeping mahonia distribution following deglaciation is also supported by recent research on the distribution of other disjunct plant species found in the Cypress Hills. For example, a study of the phylogeography of pine sap (Monotropa hypopitys), revealed the probability of glacial refugium in the western and eastern United States. ${ }^{31}$ Pinesap's current disjunct distribution in the Cypress Hills is postulated to be the result of colonization north from the western United States during deglaciation. Similarly, Engelmann spruce (Picea engelmannii), whose distribution in Canada is currently confined to the Rocky Mountain region in Alberta as well as parts of British Columbia, is found in the Cypress Hills in hybrids with white spruce. The presence of white spruce-Engelmann spruce hybrids in the Cypress Hills is argued to be the result of hybridization in its refugium in the Montana-Wyoming area followed by northward expansion of those hybrids with glacial retreat. ${ }^{32}$

\section{Acknowledgements}

The author wishes to thank Kelvin Kelly (Saskatchewan TPCS) for arranging for RCS to complete the two range surveys of CHIP - West Block. Tanya Lawson, Park Ranger for the West Block, assisted with field logistics. Amie Enns of SCDC confirmed that creeping mahonia had not previously been observed in Saskatchewan. Bonnie Smith, assistant curator at the University of Calgary herbarium, confirmed the identification of the creeping mahonia species collected. And lastly, thanks to Jon Boyle, Renny Grilz, Jacqueline Redburn, and three anonymous reviewers for commenting on earlier drafts of this manuscript.

1. THORPE, J. 2007a. Saskatchewan Rangeland Ecosystems, Publication 1: Ecoregions and Ecosites. Saskatchewan Research Council Publication No. 
11881-4E07. Saskatchewan Prairie Conservation Action Plan. Regina, SK. $40 \mathrm{pp}$.

2. THORPE, J. 2007b. Saskatchewan Rangeland Ecosystems, Publication 4: Communities on the Loam Ecosite. Saskatchewan Research Council Publication No. 11881-4E07. Saskatchewan Prairie Conservation Action Plan. Regina, SK. 48 pp.

3. BREITUNG, A.J. 1954. A botanical survey of the Cypress Hills. Canadian Field-Naturalist 68: 55-92.

4. ROWE, J.S. 1959. Forest Regions of Canada. Canada Department of Northern Affairs and Natural Resources. Queen's Printer. Ottawa, ON. 71 pp.

5. MOSS, E.H. 1955. The vegetation of Alberta. Botanical Review 21:493-567.

6. NEWSOME, R.D., AND R.L. DIX. 1968. The forests of the Cypress Hills, Alberta and Saskatchewan, Canada. American Midland Naturalist 80(1):118-165.

7. ACHUFF, P.L. 1994. Natural Regions, Subregions and Natural History These of Alberta: A Classification for Protected Areas Management. Alberta Environmental Protection, Parks Services. Edmonton, AB. 72 pp.

8. NATURAL REGIONS COMMITTEE. 2006. Natural Regions of Alberta. Compiled by D.J. Downing and W.W. Pettapiece. Government of Alberta. Publication No. T/852. Edmonton, AB. $254 \mathrm{pp}$.

9. STRONG, W.L., AND K.R. LEGGAT. 1981. Ecoregions of Alberta. Alberta Energy and Natural Resources, Resource Evaluation and Planning Division. ENR Technical Report T/4. Edmonton, AB. 64 pp.
10. STRONG, W.L., AND K.R. LEGGAT. 1992. Ecoregions of Alberta. Alberta Forestry, Lands and Wildlife. Publication No. T/245. Edmonton, AB. 59 pp.

11. ACTON, D.F., G.A. PADBURY, AND C.T. STUSHNOFF. 1998. The Ecoregions of Saskatchewan. Canadian Plains Research Center. Regina, SK. 204 pp.

12. FLORA OF NORTH AMERICA EDITORIAL COMMITTEE (FNAEC). 1997. Flora of North America, Volume 3: Magnoliphyta: Magnoliidae to Hamamelidae. Oxford University Press, NY. 616 pp. http://www.efloras.org (accessed October 1, 2011)

13. MOSS, E.H. 1983. Flora of Alberta: An Manual of Flowering Plants, Conifers, Ferns and Fern Allies Found Growing Without Cultivation in the Province of Alberta, Canada. Second Edition Revised by J.G. Packer. University of Toronto Press, Toronto, ON. 687 pp.

14. HITCHCOCK, C.L., AND A. CRONQUIST. 1973. Flora of the Pacific Northwest: An Illustrated Manual. University of Washington Press. Seattle, WA. 730 pp.

15. DOUGLAS, G.W., G.B. STRALEY, D.V. MEIDINGER, AND J. POJAR (editors). 1998. Illustrated Flora of British Columbia, Volume 2: Dicotyledons (Balsaminaceae Through Cucurbitaceae). B.C. Ministry of Environment, Lands \& Parks and B.C. Ministry of Forests. Victoria, B.C. 401 pp.

16. SASKATCHEWAN CONSERVATION DATA CENTRE. 2011a. Saskatchewan Vascular Plant Species List (October 2011 version). Saskatchewan Ministry of Environment. Regina, SK. 156 pp. http:// www.biodiversity.sk.ca/Docs/vasc.pdf. (accessed November 15, 2011). 
17. NATURESERVE EXPLORER: AN ONLINE ENCYCLOPEDIA OF LIFE [WEB APPLICATION]. 2011. Arlington, VA. http://www.natureserve.org/explorer/ (accessed October 1, 2011).

18. THE UNIVERSITY OF MONTANA HERBARIUM (WEB APPLICATION). 2011. Berberis repens records. http:// herbarium.dbs.umt.edu/database/ Displayltem.aspx?id=Berberis \%20 repens\&locality $=$ (accessed November 4, 2011)

19. SASKATCHEWAN PRAIRIE CONSERVATION ACTION PLAN GREENCOVER COMMITTEE. 2008. Rangeland Health Assessment: Native Grassland and Forest. Prairie Conservation Action Plan. Regina, SK. $82 \mathrm{pp}$.

\section{SASKATCHEWAN CONSERVATION} DATA CENTRE. 2011b. Tracked Species for Vascular Plants (October 2011 version). Saskatchewan Ministry of Environment. Regina, SK. 40 pp. http:// www.biodiversity.sk.ca/Docs/vasctrak. pdf. (accessed November 15, 2011).

21. DE VRIES, B., AND C.D. BIRD. 1968. Additions to the vascular flora of the Cypress Hills, Alberta. Blue Jay 26:98-100.

\section{RANGELAND CONSERVATION} SERVICE LTD. (RCS). 2000. Cypress Hills Interprovincial Park (Centre Block) Vegetation and Range Resource Inventory. Unpublished report prepared for Saskatchewan Environment and Resource Management. Swift Current, SK.

23. RANGELAND CONSERVATION SERVICE LTD. (RCS). 2001. Cypress Hills Interprovincial Park (Alberta) Vegetation and Range Resource Inventory. Unpublished report prepared for Alberta Environment, Natural Resources Service. Lethbridge, AB.

\section{RANGELAND CONSERVATION} SERVICE LTD. (RCS). 2003. Cypress Hills Interprovincial Park (West Block) Vegetation and Range Resource Inventory. Unpublished report prepared for Saskatchewan Environment. Swift Current, SK. 102 pp.

25. RANGELAND CONSERVATION SERVICE LTD. (RCS). 2008. Cypress Hills Interprovincial Park (Centre Block) Vegetation and Range Resource Inventory. Unpublished report prepared for Saskatchewan Ministry of Tourism, Parks, Culture and Sport. Swift Current, SK. 111 pp.

26. TANNAS, C. 2003. Common plants of the western rangelands, Volume 2: Trees and shrubs. Alberta Agriculture. Edmonton, AB.192 pp.

27. RUSSEL, L.C. 1951. Land snails of the Cypress Hills and their significance. Canadian Field-Naturalist 65:174-175.

28. WHEELER, N.C., AND R.P GURIES. 1982a. Population structure, genic diversity, and morphological variation in Pinus contorta Dougl. Canadian Journal of Forest Research 12:595-606.

29. WHEELER, N.C., AND R.P GURIES. 1982b. Biogeography of lodgepole pine. Canadian Journal of Botany 60:18051814.

30. STRONG, W.L., AND L.V. HILLS. 2005. Late glacial and Holocene palaeovegetation zonal reconstruction for central and north-central North America. Journal of Biogeography 32:1043-1062.

31. BEATTY, G.A., AND J. PROVAN. 2011. Phylogeographic analysis of North American populations of the 
parasitic herbaceous plant Monotropa hypopitys L. reveals a complex history of range expansion from multiple late glacial refugia. Journal of Biogeography 38:1585-1599.
32. STRONG, W.L., AND L.V. HILLS. 2006. Taxonomy and origin of present-day morphometric variation in Picea glauca (x engelmannii) seed-cone scales in North America. Canadian Journal of Botany 84:1129-1141.

\section{NATURE NOTES AND LETTERS}

\section{FIRST RECORD OF LICHENS FOR HASBALA LAKE, SASKATCHEWAN}

BERNARD DE VRIES

The purpose of this paper is to document 39 lichens, including 2 subspecies, 1 form, and 2 rare taxa for Hasbala Lake of Saskatchewan.

No earlier lichenological studies for Hasbala Lake (5957 N 10200 W) are known. A first detailed survey of the Hasbala Lake region ecosites, including lichens, was made by the Forest Ecosystem Classification Survey in 1997. ${ }^{11}$ A subsequent botanical survey of the southwest Hasbala Lake region was made by de Vries $^{3}$ as a supplement to Argus. ${ }^{1}$ During this survey a few lichens were observed and incorporated in this paper, denoted with an asterisk ( $\left.{ }^{*}\right){ }^{3}$

\section{Location of Hasbala Lake}

Hasbala Lake lies well within the subarctic section of northeastern Saskatchewan and is part of the taiga ecozone, which supports open subarctic lichen woodlands with mixed forest-tundra. ${ }^{6.7}$

This ecozone is dominated by coniferous taiga vegetation. The predominant tree species is Black Spruce (Picea mariana) both in upland sites and in the very extensive poorly-drained peatlands where it commonly grows with tamarack (Larix laricina). White Spruce (Picea glauca) is restricted to sheltered valley bottoms and lake shores. A minor broad-leaved component is found in some upland sites in the form of scattered White birch (Betula papyrifera). The area is also characterized by ericaceous shrubs and occasional Willow (Salix).

Lichen woodlands is the dominant forest type in the uplands, characterized by an open canopy structure and extensive mats of terricolous lichens, e.g. Reindeer lichens (Cladonia), Foam lichens (Stereocaulon) and Iceland lichens (Cetraria) in order of dominance, partnered with a diverse assemblage of epiphytic lichens attached mainly to tree bark. Feather mosses (Pleurizium schreiberi) and (Hylocomium splendens) are also common in upland forests.

Lowland forests are characteristically very open with a predominant ground cover of Peatmoss (Sphagnum), and other bryophytes, although lichens are sometimes an important component of the ground and epiphytic flora in peatlands. ${ }^{5}$

As more sampling is done, the rate at which new species are acquired falls off, because all but the rarest species have been collected. ${ }^{11}$ 